\title{
Research on a Buddha Mountain in Colonial-Period Korea: A Preliminary Discussion
}

\author{
Sunkyung Kim
}

check for

updates

Citation: Kim, Sunkyung. 2021. Research on a Buddha Mountain in Colonial-Period Korea: A Preliminary Discussion. Religions 12: 551. https://doi.org/10.3390/rel12070551

Academic Editor: Roy C. Amore

Received: 7 June 2021

Accepted: 30 June 2021

Published: 19 July 2021

Publisher's Note: MDPI stays neutral with regard to jurisdictional claims in published maps and institutional affiliations.

Copyright: (C) 2021 by the author. Licensee MDPI, Basel, Switzerland. This article is an open access article distributed under the terms and conditions of the Creative Commons Attribution (CC BY) license (https:// creativecommons.org/licenses/by/ $4.0 /)$.
Independent Researcher, Irvine, CA 92620, USA; skpolokim@gmail.com

\begin{abstract}
Buddhist art became the focus of discussion when Japanese scholars began to construct Korean art history as an academic discipline. This paper presents a case study of how a particular Buddhist site, Mount Nam in Kyŏngju, was recognized, researched, and represented during the colonial period (1910-1945). By analyzing representative Japanese publications on the subject, I argue that there existed disconnection between the colonial government and the site-researchers. I re-evaluate the conventional narrative that the colonizers regarded Buddhist statues as "art" removed from their original religious setting. This paper reveals a more layered picture of the early years of historical discourse on the so-called Buddha Mountain and Buddhist sculptures of Korea.
\end{abstract}

Keywords: Buddhism; Buddhist art; Silla; Kyŏngju; Mount Nam; colonial period; GovernmentGeneral of Korea; Ōsaka Kintaro; Oba Tsunekichi

\section{Introduction}

During the colonial period (1910-45), Korean art history began to take shape as an academic discipline guided by Japanese administrators and scholars. ${ }^{1}$ Buddhist art was the focal point of their discussions. ${ }^{2}$ Why did they have such a strong interest in Buddhist art? The foremost reason is the fact that the Japanese saw Buddhism as a legitimate counterpart to the Christianity of Western civilization. In their minds, they believed that Buddhism could function as one of the bases for the imperial policy of the Greater Asian Co-Prosperity. Whereas the colonial Government-General of Korea (Chōsen sōtokufu) purposefully portrayed Chosŏn's Confucian heritage and royal paraphernalia as ceremonial custom in a nostalgic yet spiritually hollow sense (Maliangkai 2017, p. 25), it considered Buddhism as a common thread with which they could narrate the history of all Asia. Japanese scholars elevated Buddhism as the essence of the Eastern Spirit, and its visual culture as its splendid achievement. ${ }^{3}$

Second, Buddhist sculpture was thought to be the apex of Asian art in much the same way that ancient Greek-Roman sculpture was the apex of Western art. This interpretative frame was created for Japanese art history by Okakura Tenshin (also known as Okakura Kakuzō, 1863-1913) and continued to operate in the discourse on Korean art history that followed. ${ }^{4}$

Third, an investigation of the colonized territory inevitably involved surveys of Korea's cities, villages, roads, hills and mountains; and Buddhist sanctuaries and objects were scattered throughout these locations. Ruins of the ancient Buddhist sites were frequently spotted. Such ubiquity spurred the colonial administrators' interest in restoring them as part of their imperial agenda of cultural enlightenment for the newly annexed territory in the peninsula. Chosŏn's anti-Buddhist policy was an easy target, one that the colonizers blamed for the "decline of Korea's culture". Such argument then normalized the call for a savior, namely Japan.

Lastly, the newly arising tourism industry, made possible with the rise of railroads in Japan's colonies, sought scenic spots and indigenous attractions. Buddhist temples, pagodas, and statues as well as the royal tombs of the Silla period (57 B.C.E.-935 C.E.) 
became exotic settings for photo-ops for visitors. ${ }^{5}$ Among several touristic destinations, Kyŏngju was particularly known for its rich Buddhist art and royal Silla burial mounds, whereas P'yŏngyang, another popular spot, was scoured for traces of the Han Commandery in Nangnang (C. Lelang). Kyŏngju especially evoked a feeling of nostalgia in Japanese visitors by reminding them of their oldest capital, Nara. At the same time, Kyŏngju's charm seems to have stemmed from its image as being in complete ruins, unlike Nara where ancient temple buildings still existed (Kim 2006, pp. 181-82). For instance, Yasuda Yojūrō, a renowned writer of the time, wrote in his travelogue "Keishū (K. Kyŏngju)" of 1933, "The ruins of East Asia exist in Kyŏngju ... There is nothing comparable to Tōdaiji, Hōryuji, Yakushiji or Tōshōdaiji of Nara. All are ruins and relics". ${ }^{6}$ A similarly melancholic sentiment is found in Kobayashi Hideo's writing in 1938 "Keishü". He wrote, "the scene in the farming village (of Kyŏngju) bears a dark and saddened mood everywhere under the gloomy weather". ${ }^{\text {? }}$

Recent scholarship on Japan's colonial cultural policy elucidates the overall process by focusing primarily on the colonizer's view and intention. This included instilling the Korean audience with an inferiority complex; positioning Japan as the legitimate caretaker of ancient monuments hitherto abandoned; situating Japan as a gateway to modernity; promoting tourism using images of the exotic past; and forcefully unifying two countries into one based on cultural assimilation. I believe all of those were driving forces on the colonizer's part. How the policy and project was implemented, however, had diverse forms. For instance, how a Silla king's tomb was approached by a Tokyo Universitytrained archaeologist in the 1910s was radically different from how a Buddha statue was represented by a Kyŏngju-based Japanese emigrant in the 1930s despite the commonality that they were colonizers researching Silla heritage following the Government-General's command ${ }^{8}$ How tightly and faithfully each participant followed the Government-General's agenda and protocol is also an open question.

It thus seems necessary to discern their approaches and interpretations depending on the time period, major agents, and monuments/ objects. ${ }^{9}$ For instance, the GovernmentGeneral and local communities had dissimilar goals and interests in mind at times, as witnessed in some conflicts regarding the direction of heritage management projects. One notable source of conflict was where to store relics that had been sensationally excavated in 1921 from the Gold Crown Tomb; government-sponsored scholars such as Sekino Tadashi (1868-1935) and Hamada Kosaku (1881-1938); and Kyŏngju-based Japanese such as Moroga Hideo (d. 1954) ${ }^{10}$ and Ōsaka Kintaro (1877-1974) offered two opposing recommendations (Kim 2013, pp. 211-12). The former wanted to move the relics to Seoul whereas the latter attempted to keep them locally in Kyŏngju. Based on recently advanced scholarship on heritage management in colonial Korea, now we can further our understanding of such complexity and dissonance regarding Buddhist art, too. I believe that it can be done by narrowing the scope of discussion while still keeping in mind its broad implication.

This paper presents a preliminary case study of how a particular Buddhist site was recognized, researched, and represented during the colonial period. ${ }^{11}$ The material for such inquiry is the so-called Buddha Mountain, namely Mount Nam in Kyŏngju. Owing a great debt to the previous literature in the field, I attempt to tease out some of the distinct discourse and images regarding this peculiar mountain. ${ }^{12}$

\section{Site Surveys on Mount Nam}

In 1902, Sekino Tadashi, a Tokyo Imperial University-trained architect, came to survey the art and architecture of Korea. He chose three locations for his field research: Kyŏngju, Silla's capital for a thousand years (57 B.C.E.-935 C.E.); Kaesŏng, Koryŏ's capital for five hundred years (918-1392 C.E.); and Kyŏngsŏng (present-day Seoul), Chosŏn's capital for the last five hundred years (1392-1910 C.E.).

Japanese government-sponsored researchers, including Sekino Tadashi, found Kyŏngju to be the best candidate for their rhetoric of cultural assimilation. In particular, their main focus was the mythical story of Jingū-kōgō's incursion into the peninsula, which was said 
to have taken place in the Silla territory. ${ }^{13}$ The first generation of Japanese field researchers in Korea thus paid attention to surveying royal tombs and excavating Silla burial goods. ${ }^{14}$

As for art history, however, Sekino Tadashi regarded Buddhist monuments and sculpture as a barometer of cultural achievement. He thus considered Silla to be the golden age of Korean art since it was a time when Buddhist art noticeably flourished. In fact, his emphasis on Buddhist monuments already appeared in his study of Japanese art before he came to Korea. As early as 1895, upon graduating Tokyo Imperial University, he wrote a thesis on Phoenix Hall, an 11th-century Buddhist sanctuary in Byōdōin, and praised it as the epitome of Japanese art (Takagi 2004, p. 175). He continued to hold the view that Silla was the climax of Korean art, as evidenced in Korean Art History (Chōsen bijutsushi) (1932) ${ }^{15}$ This book established a frame to narrate the development of Korean art in terms of its historical context, level of achievement, and its relationship to Chinese art.

From such perspective, the crown jewel of Korean art was Sŏkkuram, the Buddhist sanctuary constructed on Mount T'oham in Kyŏngju in 8th-century Silla. Ever since Sone Arasuke (1849-1910), the second Colonial Resident-General of Korea (t'onggam), visited Sŏkkuram in 1909, it became the primary object of restoration as a perfect exemplar of Korea's splendid, but now-lost past.

After Korea's annexation in 1910, various groups of Japanese became interested in the historic and touristic sites of Kyŏngju. In addition to professionally trained archeologists, ethnologists, and anthropologists, administrators sent from the metropole and even Japanese emigrants living in Kyŏngju actively participated in surveying ancient sites and monuments of Silla. Some founded a small coterie called "Silla Society (Shiragi kai)" with a group of Korean locals. The Silla Society soon evolved into the Society for the Preservation of Historical Remains of Kyŏngju (Keishū koseki hozonkai) in 1911. ${ }^{16}$ As Kim Hyŏnsuk argues, the Society was not a natural product of homegrown movements or an apolitical organization of Kyŏngju residents; rather, it was a purposefully organized society led by Japanese administrators. ${ }^{17}$ Such character is indicated in the fact that their financial campaigns to support restoring Kyŏngju's ruined sites received support from the first Governor General (ch'ongdok), Terauchi Masatake (1852-1919) and received help from other Japanese administrators as well as high-ranking Korean officials (Kim 2007, pp. 570-71).

Mount Nam, however, did not seem to be of primary interest to either governmentsponsored scholars or the Society for the Preservation of Historical Remains of Kyŏngju. This disinterest seems surprising when one considers that Terauchi Masatake's visit to Sŏkkuram in 1912 sparked unprecedented interest in Silla's Buddhist art. Even other Buddhist statues drew attention as comparable examples that offered an interpretative lens through which to situate the masterpiece, framing Sŏkkuram sculpture within the historical context. However, fieldwork at Mount Nam was sporadic, if not neglected altogether.

Below is the chronological outline of the recorded surveys on sites on Mount Nam and related records, which shows sporadic work. ${ }^{18}$

1. Meiji 35 (1902) Sekino Tadashi visited Mount Nam, but only focused on one area, the remnants of Namsan Fortress.

2. Meiji 39 (1906) Imanishi Ryū described Namsan Fortress, the temple sites on both sides of the fortress, and ruined pagodas. However, his fieldwork was partial, since he did not even mention the P'osŏkchŏng water channel at the foot of Mount Nam.

3. Meiji 42 (1909) Sekino Tadashi's re-investigation and Torii Ryūzō's survey focused on the sites at the foot of Mount Nam. They found cinerary urns, stone tools and earthen wares outside Namsan Fortress.

4. Taishō 4 (1915) A seated Buddha statue was moved from Samnŭnggye on Mount Nam and displayed at the Chosŏn Industrial Exhibition (J. Chōsen bussan kyōshinkai; K. Chosŏn mulsan konginhoe) in celebration of a five-year anniversary of the annexation.

5. Taishō 5 (1916) Moroga Hideo introduced 20 temple sites on the mountain in his Study of Temples and Historical Remains of Silla (Shiragi jiseki $k \bar{o}$ ). Around this time, researchers came to know that a group of tomb sites, Neolithic sites, Buddhist statues, pagodas, and stone lantern holders existed at the foot of the mountain. 
6. Taishō 9 (1920) Buddhist monuments of Mount Nam were introduced as a part of a tourist itinerary in Silla's Ancient Capital Kyŏngju (Shiragi kyūto Keishū) (Araki 2020a, p. 9).

7. Taishō era (1912-25) Photos of and field reports on Mount Nam were completed by Moroga Hideo, Kodaira Ryōzō, Ōsaka Kintaro and Tanaka Kamekuma, and later published.

8. Taishō 12 (1923) Oba Tsunekichi, who was directed to examine the Paeri Triad, became interested in Mount Nam Buddha sculpture. With Koizumi Takao, he discovered 3-4 additional monuments. They examined a monk-shaped statue on a three-tiered lotus pedestal at Yongjangsa.

9. Taishō 14 (1925) The Colonial Forestry Experiment Institute's forest project indirectly helped the Government-General Museum's survey of the monuments on Mount Nam. Fujita Ryōsaku participated in measuring and taking photos of monuments, and a few more Buddhist temple sites, statues and pagodas were discovered.

10. Shōwa 2 (1927)-Shōwa 3 (1928) The Government-General Museum, with the help of Tanaka Jūzō, made a 1/5000 map of site locations on the mountain by consulting Kyŏngju experts and surveying the entire mountain.

11. Shōwa 7 (1932) Arimitsu Kyōichi and Imaseki Mitsuo stayed in a tent on the mountain for 10 days to survey and take photos of sites and monuments. Based on Tanaka Jūzō's site map, new monuments were recorded, with the help of investigations by Ōsaka Kintaro, Moroga Hideo, and Watari Fumiya. A survey by Saito Tadashi and Fujishima Gaijirō confirmed more Silla sites on the mountain.

12. Shōwa 11-12 (1936-37) The Research Society for Historical Remains of Korea (Chōsen koseki kenkyūkai) investigated sculptures on Mount Nam along with a Nŭngji pagoda site on Mount Nang.

13. Oba Tsunekichi conducted several surveys and small-scale excavations on sites on Mount Nam, measuring monuments and taking photos with the help of Imaseki Mitsuo. For photos, he also received help from Sawa Shunichi, Saito Tadashi, Tanaka Kamekuma, and Fujita Ryōsaku. The whole project was supported by Arimitsu Kyōichi, Ōsaka Kintaro, Moroga Hideo, and Choe Sunbong. Oba Tsunekichi thanked Ōsaka Kintaro in particular for finding valley nomenclature and for matching those with the names of temple sites.

Looking through these accounts, we notice there were different perspectives toward Mount Nam in colonial Japanese works. They can be roughly grouped into three. First, the mountain was recognized as a place where some historical sites from the Neolithic Period, Bronze Age, and the Three-Kingdoms period were located. In particular, the fortresses of the Silla period were seen as strategically significant sites. In this case, only the physicality and location of the sites matter, whereas the mountain itself is not seen to have any intrinsic value.

Second, Mount Nam acted as a backdrop or supplier of Silla Buddhist art both in physical and stylistic senses. Freestanding sculptures discovered on the mountain were considered to be independent of the setting. When the cost and technology to move sculptures were manageable, the statues were taken from the original context without any thought of losing their essential value.

Such view is most clearly revealed in the case of the Bhaișajyaguru Buddha statue discovered in the Samnŭnggye valley on Mount Nam (Figure 1). First introduced by Sekino Tadashi in 1911, this statue was removed from its original site to be exhibited in 1915 in the Chosŏn Industrial Exhibition at the Kyŏngbok Palace in Seoul. ${ }^{19}$ Its display was carefully planned to re-create a pantheon of Buddhist deities similar to that of Sŏkkuram (Araki 2020a, p. 15; Araki 2020b, pp. 155-56). The seated Buddha was exhibited in front of the staircase at the center of the newly constructed museum (Figure 2). It was accompanied by two life-sized statues from another temple in Kyŏngju, Kamsansa, along with replica relief panels of Sŏkkuram. Such a mix-and-match display did not present any problem to those who focused only on the stylistic features and on showing their power in taking care of the so-called endangered ancient works in their colony. It seems likely that Sekino 
Tadashi and the colonial Government-General planned to make Samnŭnggye Buddha act as a substitute for the main Sŏkkuram Buddha, which they had been unable to move to Seoul despite several attempts. The exhibition was used to present the capability of the Japanese Government-General as a newly arising cultural power. ${ }^{20}$

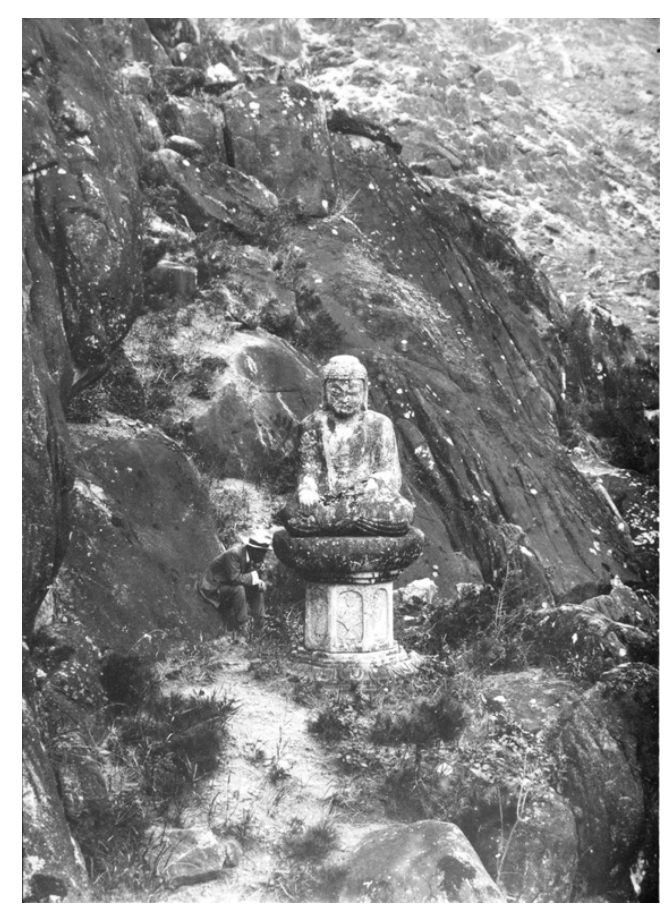

Figure 1. Seated Buddha. Samnŭnggye valley on Mount Nam. 8-9th century, Unified Silla. Gelatin dry plate from the colonial period. Courtesy of National Museum of Korea.

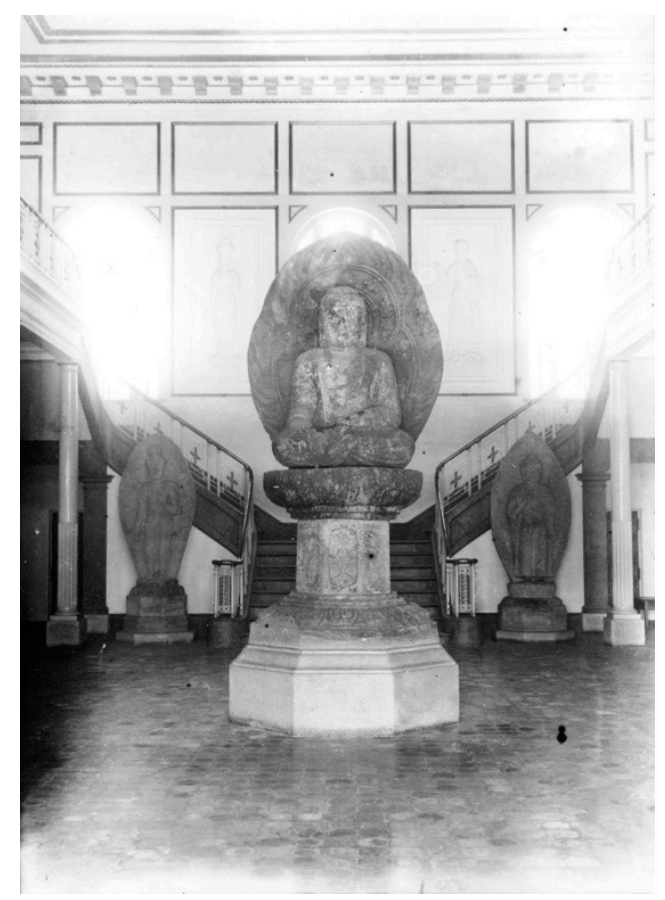

Figure 2. Seated Buddha from Samnŭnggye valley on Mount Nam. 8-9th century, Unified Silla. Displayed at Chosŏn Industrial Exhibition, 1915. Gelatin dry plate from the colonial period. Courtesy of National Museum of Korea. 
Mount Nam also offered criteria to locate other sculptures in the flow of stylistic development (if we are allowed to say that style evolved over time, as contemporaneous scholars believed). The sculptures that remained in situ became reliable, albeit imperfect, primary material for comparison to study other art works that were deemed to be more worthy in the eyes of colonial scholars.

Third, Mount Nam was valued in and of itself as a sacred realm of the so-called Buddha Mountain. Individual sites and monuments, of course, contributed to making the mountain an important backdrop; however, the mountain as a whole was finally recognized as a collectively numinous realm rather than as a venue for conglomerated works. This new approach started with Oba Tsunekichi's investigation in 1923, although a complete investigation of the mountain as a unified whole did not happen until the 1930s.

In recognizing all these different views, two figures stand out as main players in advancing research on Mount Nam: Ōsaka Kintaro and Oba Tsunekichi. I will discuss how they differed and how they contributed to the changing image of Mount Nam over a decade during the colonial period.

\section{3. Ōsaka Kintaro and Mount Nam}

Ōsaka Kintaro (also known as Ōsaka Rokuson) did not appear to be in charge of any survey or official report for Mount Nam. He was not appointed as a director of any related project. Yet, he was frequently mentioned as someone who gave valuable advice or much needed help as an expert in Kyŏngju. ${ }^{21}$ In particular, his efforts in assigning the names of the lost temples to the current ruins were frequently acknowledged (Kim 2013, p. 210). Although the issue of credibility remains in some of his work connecting temple names and actual sites (Ch'a 2006), his work has served as a starting point for further inquiry even until today. Who was this person and how did his expertise as an insider make an impact on seeing Mount Nam then and now?

Ōsaka Kintaro became the associate principal at Hoeryŏng primary school in 1907 and moved to Kyŏngju when he was appointed as the principal of the Kyŏngju public primary school in 1915. He was an active member, along with Kimura Shizuo and Moroga Hideo, of the Society for the Preservation of Historical Remains of Kyŏngju. In 1938, he became the third director of the Kyŏngju branch of the Government-General Museum.

His book, Pastimes of Kyŏngju (Shumi no Keishū), in particular, seems to have been well accepted by the Japanese at the time it was published. This book gathered together 52 articles that had been published as a series in the periodical Chōsen minpō beginning in May, 1930. The foreword was written in 1931 by Fujita Ryōsaku, the director of the Government-General Museum.

In the illustration on the book's first page, Ōsaka Kintaro was described as a man with a hammer opening an age-old cave to bring a supposedly dormant Buddha statue into the daylight. The passage reads, "I tried to open the wall to wake up a sleeping statue of Buddha (Figure 3)". Such an image of a heroic explorer and discoverer certainly recalls all previous pioneers including Terauchi Masatake, the first Governor-General in Korea. Terauchi Masatake was introduced as a heroic leader "opening the rock cave so that the 'righteousness and justice' of the sun goddess, Amaterasu, shines on the Korean people" as seen in the cover image of a comic magazine, Tōkyo Puck, September, 1910 (Duus 1995, fig. 15).

In the Pastimes of Kyŏngju, Ōsaka Kintaro dedicated 22 pages of 250 pages to Mount Nam (Ōsaka 1931, pp. 113-34). He recognized the importance of the mountain both as a source for further information on the ruined temples and as a site for living worship. For example, Ōsaka Kintaro described how he found a stone Buddha triad at Paeri on Mount Nam. Upon arriving in Kyŏngju in 1915, he had already heard about the rumor that there was a stone triad Buddha almost completely buried in front of the P'osŏkchŏng water channel. It was not until 1917, however, that he actually found it following the local children's direction. ${ }^{22}$ In 1922, anticipating Prince Kan'in no miya's visit to Kyŏngju, the Society for the Preservation of Historical Remains of Kyŏngju wanted to move the triad 
to their exhibition room, because they had a meager collection at that time. ${ }^{23}$ Due to the technical challenge of moving such weighty works, however, they ended up leaving the triad at its original location. When Ōsaka Kintaro visited it, he saw local people had stacked small stones in front of the statue while making a wish. He described the Buddha triad that remained in situ as an object of living worship by local believers. He then added that what surprised visitors to Kyŏngju was neither royal burials, Ch'ŏmsŏngdae nor ruined sites; rather "it has to be the legendary Mount Nam that was a background for countless sites and solely stood picturing a thousand years of fluctuations between glory and decline" (Ōsaka 1931, pp. 117-18).

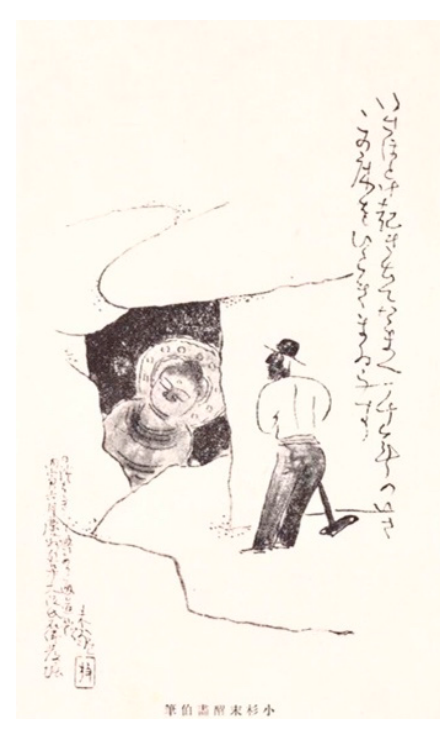

Figure 3. Frontispiece illustration. Drawing by Kosugi Misei. Pastimes of Kyŏngju, 1931.

In the meantime, in the foreword to the Pastimes of Kyŏngju, we clearly see colonial Japan's idea of Kyŏngju. There Fujita Ryōsaku states that "Kyŏngju of Korea" had shifted to "Kyŏngju of Japan" and finally had become "Kyŏngju of East Asia". ${ }^{24}$ This view was a decades-old claim continued from the article written in 1912 in the Government-General Monthly (Chōsen sōtokufu geppō). ${ }^{25}$ It says, "the ancient remains of Kyŏngju does not merely represent the pride of Kyŏngju; it is indeed the pride of Korea, then it should be the pride of our empire" (Yun 2009, p. 163). Such a statement emphasizes the colonizer's role in guarding these from looting and damage. Fujita recognized that Mount Nam was a protective mountain for the Silla people, as well as Amitābha's abode and Tusita Heaven. The mountain was regarded as a treasure house of Silla Buddhist art due to the plethora of pagodas as well as carved Buddhas and bodhisattvas in every valley and on every cliff. So positioning it as something of East Asia indicates that Japan's role had, by this point, expanded as a keeper of East Asian tradition.

In the main text of the book, the author Ōsaka Kintaro again praised Mount Nam as the climax of any tourist's visit to Kyŏngju (Ōsaka 1931, p. 122). The concentrated presence of burial mounds that impressed visitors in the Kyŏngju basin was now put aside, and Mount Nam became the symbol of Silla's spirit.

It is noteworthy that Ōsaka Kintaro continuously compared the stone statues on the mountain with Pulguksa/Sŏkkuram. He surprisingly valued the former more than the latter. According to Ōsaka Kintaro, Pulguksa and Sŏkkuram represent the most mature phase at the highest peak of Buddhist art in Silla, and so inevitably throw a shadow on its decline from that moment on. On the contrary, statues on Mount Nam evoke the solemn energy and the true reflection of Silla Buddhists' faith (Ōsaka 1931, p. 122). Here, an interesting dichotomy is delineated between the "art" of Pulguksa/Sŏkkuram and the "religion" of Mount Nam, and a sharp contrast between the doomed masterpiece and 
the dignified vigor. This idea, however, diverged in the following years as seen in the next section.

\section{Oba Tsunekichi and a Book on Mount Nam}

During one week in 1925, Fujita Ryōsaku, serving as a director of the GovernmentGeneral Museum, participated along with other surveyors in the measuring and photographing of sites, pagodas and sculptures on the mountain. Together they discovered several new monuments. What is most remarkable about this fieldwork is that they seized upon the Forest Experiment Station (Ringyō shikenjo) project on Mount Nam to pursue research on the artwork there. According to David Fedman, the Forest Experiment Station was "what was to become a flagship research institute and a central hub in the expanding network of nurseries in Korea" (Fedman 2020, p. 109). In other words, although Mount Nam was recognized for ancient sites and monuments, its overall survey was possible only in 1925 in conjunction with a more systematic and better-funded forestry project. In a way, Japan's "forest-love ideology" worked as an indirect impetus to discover the totality of Mount Nam.

Interestingly, some sites on Mount Nam were under private ownership while others were included in the forest category. The Buddha statue at Mirŭkkok, for example, was not to be moved from its original site since the lot was recognized as private property whereas the statue itself was state property (Araki 2020a, p. 23; Araki 2020b, p. 164). In contrast, Samnŭnggye statue was moved to Seoul since there was no private ownership either for the site or the statue. Araki Jun explained that it was due to the fact that most areas of Mount Nam were classified as forest (Araki 2020b, p. 164).

In his insightful book on imperial Japan's forestry policy, David Fedman points out the Japanese "colonial state appears multifarious-less a monolithic entity than a collection of like-minded technocrats, less an almighty actor than a jumble of competing interests" (Fedman 2020, p. 12). I believe that a similar point can be made about the colonial approach and policy toward Korean cultural heritage. Some Japanese who had lived in Kyŏngju or who had come to investigate the monuments, for example, had interests distinct from those of the Government-General. For instance, they might desire to pursue an academic discovery, achieve an administrative promotion, gain monetary value, ${ }^{26}$ or more effectively serve the colonial agenda. As Fedman notes, to recognize that the Japanese in Korea were enthusiastic and energetic about their efforts is not to downplay the "intensity of colonial violence. It is rather to bring new depth to our understanding of the very nature of that violence" (Fedman 2020, p. 7).

A comprehensive presentation of Mount Nam as a whole finally appeared in a book, Buddhist Sites and Monuments on Mount Nam in Kyŏngju (Keishū Nanzan no busseki) published by the Government-General in 1940. As a second volume in the series called the Catalogue of Treasures and Historical Remains of Korea (Chōsen hōmotsu koseki zuroku), it has detailed descriptions of sites and monuments in each valley, accompanied by hundreds of large plates of photos and drawings. ${ }^{27}$

The author, Oba Tsunekichi (1878-1958), came to Korea and worked with Sekino Tadashi on making replicas of Koguryŏ tomb murals in $1916 .{ }^{28}$ As an artist and an employee of the Government-General of Korea (Yun 1997, p. 217), Oba Tsunekichi became interested in Buddhist sculpture on Mount Nam in 1923 when he was sent to investigate the Paeri Buddha triad and the Yongjangsa statue which was on a three-tiered lotus pedestal. He later conducted several additional surveys and small-scale excavations on Mount Nam.

In the main text of Buddhist Sites and Monuments on Mount Nam in Kyŏngju, Oba Tsunekichi made it clear that all the descriptions and information were the result of his own work. He provided a historical overview of Mount Nam in the beginning and thoroughly explained each site and monument based on his firsthand observation and after consulting textual documents such as the Memorabilia of the Three Kingdoms (Samguk yusa), the History of the Three Kingdoms (Samguk sagi) and the Survey of the Geography of the Eastern Kingdom (Tongguk yŏji sŭngnam). He also acknowledged Ōsaka Kintaro's crucial help in identifying 
the names of each valley and temple site on Mount Nam. Below, I will discuss a few particular points from Oba Tsunekichi's report that show new images and notions of Mount Nam.

He listed over 50 temple sites and catalogued all the stone sculptures and pagoda remnants with meticulous measurements. His overly detailed measurements were probably considered necessary according to expectations for the Government-General's projects based on the assumption that Japan "possesses the scientific techniques necessary to explain the beliefs of distant lands and people" (Abe 2008, p. 125). Oba Tsunekichi also continuously re-examined the previous site report by Fujishima Gaijirō that had been published in the Kenchiku zasshi vol. 12 in 1933. He pointed out that Fujishima's work was not accurate in terms of measurements and thus presented wrong conclusions about the scale and date of some pagodas (Chōsen sōtokufu 1940, pp. 16, 23, 26, 57, 76).

Anecdotal stories of discovery and the objects' whereabouts were introduced whenever available. For example, Oba Tsunekichi recorded that the Buddha sculpture standing in the center of the stone-sculpture hall at the Kyŏngju branch of the Government-General Museum was originally from the site of Kŭmgwangsa. He added that the time of its discovery, the lower half was buried under the ground at the temple site, and the Society for the Preservation of Historical Remains of Kyŏngju moved it to the museum. ${ }^{29}$ Such record provided a narrative frame for subsequent accounts of all objects, and also offered the inside information on the role of local societies such as the Society for the Preservation of Historical Remains of Kyŏngju.

More remarkable is that Oba Tsunekichi described the entire mountain as if it were a gigantic monastery and a site-specific monument. Under such rubric, the physical condition and location of each site is explained in detail. For example, as for the Changch'anggok valley, he described "it originally comes from the inside of the Namsan Fortress, starting from below the Sŏch'angji site, passing in-between the Ch'ŏnŭnsa temple site and King Wŏnsŏng's tomb, joins the stream from the Haemongnyŏng pass, then passes by the flagpole bases of Namgansa temple, flows west through the middle of Kŭmoji pond and Najŏng well, cuts through the Önyanggado path, and finally joins the Sŏch'ŏn creek" (Chōsen sōtokufu 1940, pp. 6-7). He then mentioned that there are a great many monuments and sites along the valley, so his description of the natural environment is closely tied with understanding the character of the temples and sculptures. His explanation of each crest, valley and creek was as if tracing each structure or element in a cloistered site or an extensive art complex. ${ }^{30}$

In the meantime, his introduction of a broken stone pagoda at the Ch'angnimsa site in particular calls for our attention in that it shows the beautification of a destroyed monument, the so-to-speak, "hakaibi" (Figure 4). His introduction reads: "The pagoda made in high-quality granite is located at the temple site in the center of the hilltop. Its scale and skillful construction make it the best pagoda on Mount Nam, and one of the biggest stone pagodas of Silla. It is lamentable that some parts are missing even from the previously toppled-down state. However, major parts still lay horizontally on the spot. The remnants of the first-story body and the roof stone, albeit broken, remained layered in order. Although the second and third-story body and those above the dew-basin are missing, surviving monumental stone slabs evoke the beauty of the destruction" (Chōsen sōtokufu 1940, p. 15). Here, it is useful to remember Wu Hung's point that although architectural ruins existed in China for centuries, their status "as a prominent 'Chinese ruin' became global knowledge at this particular historical moment through a foreign system of representation" in the early 19th century (Wu 2012, p. 101). Such concept of ruination and fragmentation that was formed at the turn of the century seems to have permeated the art historical discussion later advanced by Japanese scholars. As observed by many scholars of literature and tourism, the essence of the Japanese visit to Kyŏngju sprang from the desire to discover the ruins (Hŏ 2007, p. 188). 


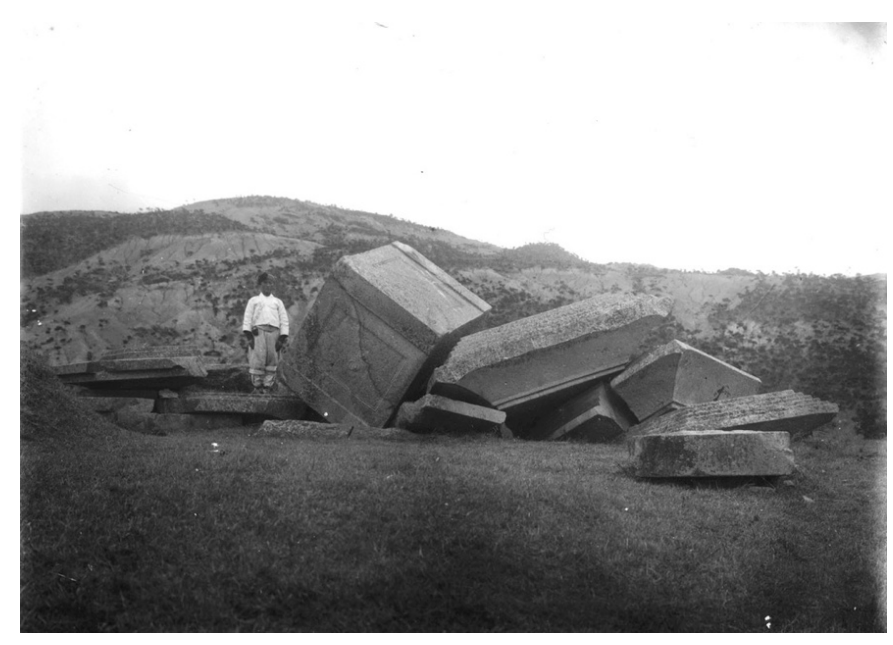

Figure 4. Broken pagoda at Ch'angnimsa site, Mount Nam. Gelatin dry plate from the colonial period. Courtesy of National Museum of Korea.

At the same time, a notable achievement in restoring the broken sculpture is acknowledged for the seated Buddha from the Samnŭnggye temple site (Figure 5). Oba Tsunekichi documented its regrettable state in 1923 when only the octagonal lotus throne remained in the original place whereas the Buddha's torso was toppled down in front, the mandorla had fallen off in the back, and the Buddha's head was found far down the hill. In December that year, the Government-General restored it to the whole, which, according to Oba Tsunekichi, became "a luminous Buddha on Mount Nam, the worthy icon for worship by sentient beings" (Chōsen sōtokufu 1940, p. 36). Here, he seemed to agree with the Government-General's policy of restoring broken pieces, but advocated for preserving the original location, especially Mount Nam.

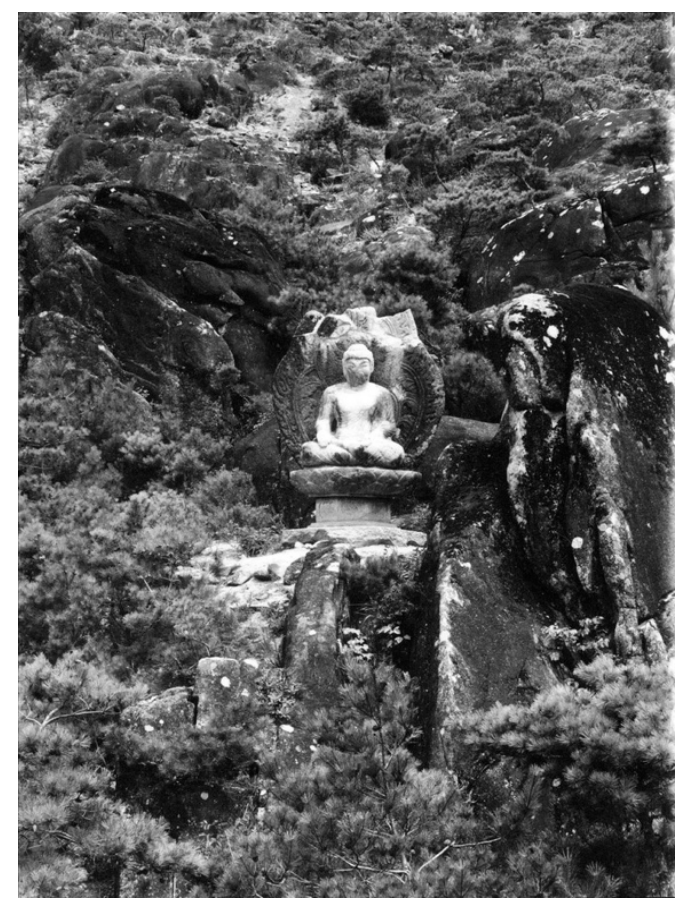

Figure 5. Seated Buddha. Samnŭnggye valley on Mount Nam. 8-9th century, Unified Silla. Gelatin dry plate from the colonial period. Courtesy of National Museum of Korea.

Another statue had a different destiny. As previously mentioned, a seated Bhaisajyaguru Buddha from the same valley was exhibited in the Chosŏn Industrial Exhibition at the 
Kyŏngbok Palace in 1915 after Terauchi Masatake had it moved to Seoul (Figure 2). Oba Tsunekichi showed reservations even about its quality, saying that the carving skill for the statue and throne was not superb, but its current state was adequate to show the late Silla's period style (Chōsen sōtokufu 1940, p. 37). Its original location had been forgotten, but Oba tracked down the location with the help of an old photo and a guide who had helped with its original transfer. It was believed to have been located at a very narrow but level location with only a size of $3.9 \mathrm{~m}$ by $6 \mathrm{~m}$ among gigantic rocks at Samnŭngge, where the steep cliff blocks access to the north and the edge meets the valley on the south and west. The location was where human visitation would be extremely rare. Here, his note stated:

"When they barely made it through this dangerously narrow cliff by climbing, but still chiseled the boulder to carve a delicate Buddha image in the gigantic rock, and worshipped him [Buddha] everyday, it is hard to interpret Silla people's faith just as their simple reverence to Buddhism. The Buddha hall and Buddha statue were not merely made as artworks either. Silla Buddhists especially chose a pure place on the mountain as an expression of their profound Buddhist doctrine. Then, this Buddha should be located at the original site in harmony with the environment in order to bear significant religious connotation and luminous authority rather than being just an artwork in a museum as it is now. We should remember that it is unthinkable that this statue should leave the valley of Mount Nam". (Chōsen sōtokufu 1940, pp. 38-39)

As is well known, the stone statue was a part of the exhibition celebrating the five years of colonial rule, a project pursued by Terauchi Masatake, who aimed to construct a museum emulating those of Europe where all the works from their colonies would be proudly displayed.

Oba Tsunekichi's view, which emphasized the importance of the original context of the artworks, is found throughout his writing. ${ }^{31}$ A recurring pattern of narrative is as follows: first he described the natural environment and location of the site, current state of a broken monument, previous efforts to restore or to move it to the Government-General Museum, a possible name of the temple or the identity of the carved deity, the measurement of the relics, and then discussed the artistic achievement, followed by the explanation of the Silla Buddhists' devotion practiced on Mount Nam.

For example, regarding the creeks of Yongjanggye and Yŏlban'gye, he wrote that the natural scenery and rock formations made this area resonate with the painting of the Buddha's Parinirvana and a collection of ten thousand things. Naturally occurring rocks in odd shapes evoke the images of descending Buddhist deities, dragons, and phoenixes, which created the impression of Mount Nam as a Buddha's abode, Maitreya's Pure Land, and the site for Amitābha's descent. Similarly, all the folklore and myths embedded in each valley and its name help convey the idea of Mount Nam as a residence for the Sākyamuni's True Body. The vista of the stone pagodas and statues at the Yongjangsa site was said to resemble the panoramic unfolding of Mount Sumeru, consisting of the miraculous heavenly touch integrated with exquisite human efforts (Chōsen sōtokufu 1940, pp. 46, 50).

It seems obvious that to Oba Tsunekichi Mount Nam meant more than a backdrop for freestanding sculptures. Remarkable in this light is his comment that the Chi'lburam sculpture on Mount Nam surpasses Sŏkkuram in that the former preserved its pristine state unlike the latter which was "secularized". He noted that carving such masterpiece of Buddhist statues in granite at Chi'lburam would have taken a long time, testifying to the strong faith and advanced masonry skills required, and fortunately this work endured for thousands of years in the elements despite its exposed location in the outdoors. Thanks to its remote location, it was possible to escape from "harmful intentions of human activities" (Chōsen sōtokufu 1940, p. 79).

Here, the harmful human activities seem to first denote the people of Koryŏ, Chosŏn and contemporary Koreans as opposed to Silla people. Oba Tsunekichi, above all, reported that a local believer arbitrarily opened up a small hermitage called $\mathrm{Ch}$ 'ilburam in order to protect the stone carving. He then lamented that she changed the physical condition and 
moved the works to a different location. It is obvious that he opposed any change made by those who were not authorized by the colonial government.

It is helpful to remember that the Government-General promulgated the Temple Act in June, 1911, which required that anyone wanting to merge, move or relinquish Buddhist temples obtain permission from the Government-General and put temple-owned assets including buildings, objects, and forests under the Government-General's control. How effectively the Temple Act worked against the interests of Korean Buddhism does not seem to be agreed upon by scholars. One thing is clear: by putting both ancient sites/monuments and contemporaneous Buddhist organizations under their direct control, colonial Japan advanced to establish their authority over the religious life of the Korean people. Although the scattered works on Mount Nam probably did not belong to any district temple at the time, Oba Tsunekichi seemed to regard only the official agency associated with the Government-General as having the authority to restore or change the works.

Second, "harmful intentions" mentioned by Oba Tsunekichi might connote any project pursued by the Japanese Government-General. As opposed to the Bhaisajyaguru statue that was moved by the Government-General to Seoul, the Ch'ilburam statue fortunately remained in situ. Here, the disconnection between the colonial government and the siteresearchers is revealed. Perhaps Oba's expertise in the holistic survey of ancient monuments and Buddhist works contributed to his stand.

Only in this light can we understand his argument that $\mathrm{Ch}^{\prime}$ ilburam is better than Sŏkkuram. Oba Tsunekichi was a chief researcher who was knowledgeable in Buddhist art as demonstrated by his writings on the iconography, doctrine, and stylistic comparison of all the statues on the mountain. Therefore, his comment that Sŏkkuram was secularized is all the more difficult to grasp. Perhaps the secularization that Oba suggested has two different layers. First, the climax of the stylistic evolution found at Sŏkkuram inevitably involved the ensuing artistic decline or mannerism in stylistic repetition. This sentiment is similar to Ōsaka Kintaro's remark noted earlier. Second, the secularization might mean the human endeavor to preserve and restore an ancient masterpiece with contemporaneous skills. Interestingly, a comparable account is found in a travelogue by a musician, Okumura Naoji. He left a record of his visit to Sŏkkuram in a journal Korea and Manchuria (Chōsen oyobi Mansh $\bar{u}$ ) in 1924, writing "I expected an old sanctuary that would recall the distant past based on the photos I had seen, but when seeing it in person, it is as new as it was just completed. The first impression was very bad. Later I heard that the photos were from long ago, and there was a recent restoration. However, in my opinion, it is only natural that material gets damaged over time, and we can discover some history from it. If they make it anew like this, it only gives a bad impression and cannot convey the historical solemnity. I heard that they not only restored the areas surrounding the grotto, but also cleansed with ascetic acid even moss of a thousand years. What the administrators have done is simply unbelievable". ${ }^{32}$

Sŏkkuram was naturally a prime target for the colonial government's project of moving and exhibiting in Seoul at first, and when the plan failed, it became the epitome of the colonial restoration effort in situ. The notoriously arbitrary restoration by the GovernmentGeneral left an indelible scar on the monument and in this sense, Oba Tsunekichi might consider it as having been desanctified and thus secularized.

On the contrary, Oba Tsunekichi held Mount Nam in high esteem as a collective site with the imprimatur, "Buddha Mountain". However, there existed a limitation. At the end of the day, the question is, "Whose Buddha Mountain?" As other administrators and researchers of the time, Oba made it clear that the Japanese should be the ones to interpret and protect Korean heritage. The right to access sites, excavate, purchase, move and restore was solely the domain of the Japanese colonial administration (Aso 2014, p. 118).

When Oba Tsunekichi recognized with nostalgia the Silla craftsmen's superb skills in Yaksugye line engraving, for example, he noted that the delicate rendering of its drapery and superb carving technique made it look graceful, as if wrapped with a thin layer of wet silk, thus resembling the Amitābha statues of the Japanese Fujiwara period. This carved 
Buddha made a deep impression on Oba. He said he wished he had met the Silla artisan who left the extraordinary work in the midst of a mountain cliff but did not leave his name (Chōsen sōtokufu 1940, p. 44). The anonymity of the sculptor and the absence of such excellence in contemporary Korea were the basis for his appreciation of Mount Nam.

This clearly echoes the logic behind the writings of a renowned art critic and philosopher, Yanagi Soetsu (also known as Yanagi Muneyoshi, 1889-1961), who was known to have deep sympathy for the Korean people and their culture. As Eiji Oguma points out, Yanagi Soetsu "respected the aesthetic creativity of 'primitive peoples,' but presumed that the ones to assign it value and to teach and guide them would be he himself and 'the Japanese,' who were on the civilized side" (Oguma 2014, p. 108). Oba Tsunekichi's approach and interpretation were no different.

\section{Conclusions}

Through a preliminary observation of the colonial-period discussion on Mount Nam, one can see a facet of the Japanese approach to Silla history, the ruins of Kyŏngju, and Buddhist monuments. The overarching theme of Japan's entitled approach to researching and restoring the monuments on Mount Nam is found throughout all fieldworks and writings. Positioning themselves as caretakers of the ancient culture of Korea was the sole basis for their efforts whether explicitly or implicitly.

Surprisingly, however, their investigation and writings were not so different from those of current Korean scholars including myself, at least in the manner of description. Possible explanations for such familiarity are: 1 . The colonizers' rhetoric was so delicate and well-developed that it does not show their true intention of plunder (sut'al or yakt'al); 2. Despite the colonial agenda, some colonizers had a genuine interest, whether because of personal, academic, monetary, or administrative pursuits; 3. Contemporary Korean scholarship somehow continues to adopt part of the previous frame of thinking and fashion of probing when it comes to art history, notwithstanding the advancement of new theories, discoveries, and researches. I hate to admit it, but the answer seems to be "all of the above".

A narrative for the heritage management and cultural policy of the GovernmentGeneral may be at risk of becoming a monolithic picture of the colonizer's intention to control ancient monuments for their own benefit and the colonized's inability to resist this control. ${ }^{33}$ It is often said that Japanese colonizers treated Buddhist statues as "art" to be exhibited in museums after taking them out of their original setting and depriving them of religious and devotional meaning (Kang 2019, pp. 19-21), just like their European counterparts did for Greek-Roman sculptures. The so-called masterpieces of Korean Buddhist statue were indeed moved, stolen, stored, and displayed in the GovernmentGeneral Museum or at its branch in Kyŏngju. However, not all Japanese administrators were proponents of such approach. In fact, some had reservations about taking such actions (Araki 2020b, p. 152). The opposition might have come from the difficulty of moving the artworks, the budget issue, or power struggles, but others show concern that removing the artwork from its original site would cause it to lose its intrinsic meaning. The picture is indeed more convoluted. Statues on Mount Nam are a case vividly demonstrating this.

In sum, two contradictory images of Mount Nam were found in Japanese writings from the 1930s: first, Mount Nam was seen as a living site for continued worship by the local people; second, it was seen as a remote and mysterious entity separated from the secular world, most notably in contrast to the secularized Sŏkkuram. Ultimately, the meaning of Mount Nam as defined and monopolized by colonial Japan was located at the junction of a forestry project and the rocky monument; nature and culturally saturated landscape; and preservation and restoration.

Funding: This research received no external funding.

Conflicts of Interest: The author declares no conflict of interest. 


\section{Notes}

1 While Japanese scholars largely initiated the study of Korean art history, there is one notable exception, Ko Yusŏp. See (Kim 2010) for a description of his contribution.

2 For a recent study on the concept of misul (J. bijutsu), "fine art" in modern Korea, see (Chŏng 2009a). Regarding the concept of sculpture in China, see (Abe 2012; Abe 2017). On the categorization of Buddhist art and sculpture in Korea, see (Kang 2010; Lee 2021).

3 Robert Sharf notes, "Buddhism's status as the cultural heritage of all Asia allowed the Japanese to affirm their cultural spiritual solidarity with the peoples of the Asian continent, while at the same time claiming Japanese spiritual superiority" (Sharf 1995, p. 110). For a recent discussion on the formation of Korean art history in comparison with Japanese art history, see (Takagi 2004, p. 175). (Pai 2013b). For a discussion on Kyŏngju and tourism, see (Yun 2009).

(Yojūrō Yasuda 1933), cited from (Но̆ 2007, p. 188).

7 (Hŏ 2007, p. 188). This was in stark contrast with popular guidebooks introducing opportunities abroad. There was a surge of such guidebooks after the Russo-Japanese War in 1905. One written in 1909 lured soon-to-be emigrants by saying, "Success comes to those who seize the opportunity ... . [Korea] is a place where there are green hills everywhere; it is a place rich in resources; it is a place where there is freedom; this is our homeland (waga kokyō)". (Yamamoto 1914, p. 13), cited from (Duus 1995, p. 322).

8 For the different roles and approaches by the employees of the Government-General, see (Kim 2016b). For reference, the number of Japanese emigrants in Korea increased from 835 in 1880 to 347,850 in 1920. For demographic information on Japanese residents overseas between 1880-1920, see Table 5 in (Duus 1995, p. 290).

9 Even when pursuing the central state's imperial mission, the Government-General of Korea sometimes acted differently from their superior/colleagues in the metropole. Such dissonance was seen in the case of Taiwan, too. (Aso 2014, pp. 96-108). For Moroga Hideo's scandal with looting a Silla royal tomb, see (Chŏng 2009b; Kim 2013; Araki 2013). The author is currently working on a more detailed analysis, which will include various writings by Japanese scholars, administrators, and visitors during the colonial period. The last decades saw increasing research on cultural policies and the beginnings of archeology and art history in Korea during the colonial period. To name but a few written in English, consider (Pai 2001, 2010, 2013a; Maliangkai 2017; Kang 2019). For an overview of research on this myth, see (Farris 1998, pp. 57-68; Schmid 2002, pp. 147-48). In addition, Japanese administrators and surveyors' interest in Kyŏngju was drawn from some anecdotes of Toyotomi Hideyoshi's invasion in 1592. Representative scholars include Imanishi Ryū(1875-1932), Torii Ryūzō (1870-1953), and Kuroita Katsumi (1874-1946). For a thorough history of the cultural policies and major figures investigating the royal tombs and monuments, see (Kim 2007).

The Korean Art history, written in Japanese, was one of the earliest art history textbooks available to Korean students (Takagi 2004, pp. 183-89).

Kimura Shizuo, who served as a colonial administrator to Kyŏngju in 1910, was a central figure in the founding of the Silla Society and then the Society for the Preservation of Historical Remains of Kyŏngju with Moroga Hideo and Ōsaka Kintaro. (Kim 2007; Chŏng 2009b; Kim 2013). For an overview of the colonial-era field research of historical remains in Korea, see (Yi 2008). This chronological sketch is based on (Chōsen sōtokufu 1940; Pai 2010; Kim 2013; Kungnip Kyŏngju munhwajae yŏn'guso 2020). (Araki 2020a, p. 13; Araki 2020b, p. 155). Araki Jun's research is very informative and is based on contemporaneous records including Maeil sinbo dailies, Government-General documents, personal essays and testimonies. His observation on the Samnŭnggye-statue exhibition in relation to the colonial government's failed plan to move Sŏkkuram to Seoul is insightful.

As for a recent discussion on how the Chosŏn Industrial Exhibition of 1915 positioned the visitors as the modern subjects of a new national identity, see (Park 2021).

Ōsaka Kintaro was also influential in researching Silla folklore (Kim 2014; Kim 2016a).

He identified the location as Ambanggok菴房谷.

(Ōsaka 1931, p. 116). Kan'in no miya Kotohito shinnō閑院宮載仁親王 is Prince Kotohito (1865-1945) from the Japanese imperial family and Chief of the Imperial Japanese Army General Staff in 1931-40. Fujita Ryōsaku, "Foreword," in (Ōsaka 1931, p. 1).

(Chōsen sōtokufu 1912). Kuksa Py'ŏnch'an wiwŏnhoe, http:/ / db.history.go.kr/item/level.do?sort=levelId\&dir=ASC\&start=1\&li mit $=20 \&$ page $=1 \&$ pre_page $=1 \&$ setId $=-1 \&$ totalCount $=0 \&$ prevPage $=0 \&$ prevLimit $=\& i t e m I d=$ ma\&types $=\&$ synonym $=$ off $\&$ chiness $C$ har=on\&brokerPagingInfo=\&levelId=ma_027_0180_0030\&position=-1 (accessed on 5 May 2021). For the illegal export of Korean cultural property during the colonial period, see (Araki 2017). The plate numbers only go up to 110, but most of them have more than one photo, so the total number of images is more than several hundred. Additionally, the body of the text has quite a few photos and illustrations.

28 (Kim 2016b, p. 9). We can still find his work such as "replica of the white tiger mural" in Chinp'ari Tomb. No.1 on the National Museum of Korea website. 
(Chōsen sōtokufu 1940, p. 6). Oba Tsunekichi mentioned that this information was provided by Moroga Hideo.

30 He had interest in the style and iconography as typically seen in the section for the Buddha triad found from Changch'anggok stone chamber. He described the triad as the best example of Silla stone art preceding Sŏkkuram, and left the identity of the Buddha to future discussion by pointing out that Silla Buddha images did not necessarily follow the textual doctrine. His questioning on why the Buddha triad was installed inside a tomb stems from a preconceived idea about the stone chamber as a burial site (Chōsen sōtokufu 1940, pp. 9-10).

31 His holistic observation is particularly noticeable in explaining the Buddha statue seated on the round rock throne at the Sangbong of the Yongjangsa site. "The Buddha statue is located on the narrow ridge that extends southward from the summit of Mount Kŭmo, and on the west side of its middle on the gentle slope. Surrounding is the beautiful field of small pebbles of weathered granite. The front of the statue has an open area only about $9 \mathrm{~m}$ long abruptly faced by a deep valley and looking over the Pulguksa and Mount T'oham to the east. It is hard to consider the Buddha statue on a natural rock base on this steep cliff as a part of a temple site, and moreover there is no space for temple buildings. Naturally it must have been regarded as a heavenly made realm of the Buddha and as a space for ardent practice and worship". (Chōsen sōtokufu 1940, pp. 54-55). (Okumura 1924, pp. 94-95), cited from (Yun 2009, pp. 171-72).

33 As for criticism of such a two-dimensional narrative, see (Richard Jaffe 2010, p. 2).

\section{References}

Abe, Stanley. 2008. China, the Buddha, and Modern Aestheticism. In Re-imagining Asia: A Thousand Years of Separation. Edited by Shaheen Merali. London: SAQI, pp. 124-33.

Abe, Stanley (Sŭt'aenri). 2012. Chungguk chogak ŭi kŭndaejŏk sun'gan. Misul charyo 82: 63-92.

Abe, Stanley. 2017. Sculpture: A Comparative History. In Comparativism in Art History. Edited by Jas Elsner. London and New York: Routledge, pp. 94-108.

Araki, Jun. 2013. Ilche singminjigi Kyŏngju Ilbonin imin e taehan misijŏk koch'al: Kyŏngju ŭp Sŏgyŏngsa ŭi sŏngnip kwajŏng ŭl chungsimŭro. Ch'asedae inmun sahoe yŏn'gu 9: 155-75.

Araki, Jun. 2017. Ilche sigi Kyŏngju chiyŏk munhwajae ŭi panch'ul kyŏngno e taehan yŏksa illyuhakchŏk koch'al. Han'guk munhwa illyuhak 50: 41-85.

Araki, Jun. 2020a. Ilche kangjŏmgi Kyŏngju Namsan ch'ogi pulchŏk chosa yŏn'gu. In Kyŏngju Namsan pulgyo munhwajae ŏje wa onŭl. Kyŏngju: Kungnip Kyŏngju munhwajae yŏn'guso, pp. 7-26.

Araki, Jun. 2020b. Ilche kangjŏmgi Kyŏngju Namsan Samnŭnggye Yaksa yŏrae chwasang panch'ul kyŏngwi e taehan koch'al. Munhwajae 53: 150-69.

Aso, Noriko. 2014. Public Properties: Museums in Imperial Japan. Durham and London: Duke University Press.

Ch'a, Sunch'ŏl. 2006. Ilche kangjŏmgi Kyŏngju chiyŏk samyŏng ch'ujŏng kwajŏng kŏmt'o. Sillasa hakpo 7: 173-207.

Chŏng, Hogyŏng (Chung, Ho-kyung). 2009a. Han'guk kŭndae ki misul yongŏ ŭi toip kwa kŭ chedojŏk insik. Hyŏndae misulsa yŏn'gu 26: 7-36.

Chŏng, Insŏng. 2009b. Ilche kangjŏmgi Kyŏngju kojŏk pojonhoe wa Moroga Hideo. Taegu sahak 95: 1-39.

Chōsen sōtokufu. 1912. Keishū no koseki ni tsuite. Chōsen sōtokufu geppō 2: 11.

Chōsen sōtokufu. 1940. Keishū Nanzan no busseki. Chōsen hōmotsu koseki zuroku. 2. Keijō: Chōsen sōtokufu.

Duus, Peter. 1995. The Abacus and the Sword: The Japanese Penetration of Korea, 1895-1910. Berkeley, Los Angeles and London: University of California Press.

Farris, William Wayne. 1998. Sacred Texts and Buried Treasures: Issues in the Historical Archeology of Ancient Japan. Honolulu: University of Hawai'i Press, pp. 57-68.

Fedman, David. 2020. Seeds of Control: Japan's Empire of Forestry in Colonial Korea. Seattle: University of Washington Press.

Hŏ, Pyŏngsik (Huh, Byung Shik). 2007. Singminji ŭi changso, Kyŏngju ŭi p'yosang. Pigyo munhak 43: 185-206.

Jaffe, Richard. 2010. Editor's Introduction: Religion and the Japanese Empire. Japanese Journal of Religious Studies 37: 1-7. [CrossRef]

Kang, Hŭijŏng (Kang, Heejung). 2010. Ilche kangjŏmgi ŭi Chosŏn pulgyo misul chosa wa pogwŏn-Han'guk pulgyo misul ŭi ch'ulbalchŏm. Misulsa wa sigak munhwa 9: 146-73.

Kang, Hŭijŏng (Kang, Heejung). 2019. The Remains from Ancient Times: Newly Formed Connections with Buddhist Culture Designated as "Art" or "Cultural Assets". Journal of Korean Religions 10: 11-43.

Kim, Hyŏnsuk. 2006. Kŭndae sigak munhwa sogŭi Silla: Sŏkkuram ŭl chungsimŭro. Han'guk kŭnhyŏndae misulsahak 17: 173-205.

Kim, Hyŏnsuk. 2007. Ilche kangjŏmgi Kyŏngju kojŏk pojonhoe ŭi palchok kwa hwaldong. In Sigak munhwa ŭi chŏnt'ong kwa haesŏk. Seoul: Yekyŏng, pp. 561-83.

Kim, Youngna. 2010. The Achievements and Limitations of Ko Yu-seop, a Luminary in Korean Art History. Archives of Asian Art 60: 79-87.

Kim, Tongha (Kim, Dongha). 2013. Ilche kangjŏmgi Kyŏngju chiyŏk pulgyo yujŏk chosa wa Kyŏngju kojŏk pojonhoe ŭi Keishū koseki oyobi ibutsu chōsa. Pulgyo misulsahak 15: 205-33.

Kim, Kwangsik. 2014. Shiragi densetsu no hakkensha, Ōsaka Kintaro. In Shokumin jiki ni okeru Nihongo Chōsen setsuwashū no kenkyū. Tokyo: Bensei shuppan, pp. 149-74.

Kim, Kwangsik. 2016a. Nakamura Ryohei ŭi Silla sinhwa chŏnsŏl surok kwajŏng e taehan yŏn'gu. Ilbonhak yŏn'gu 58: 33-57. 
Kim, Taehwan. 2016b. Chosŏn ch'ongdokpu kojŏk chosa saŏp esŏ Fujita Ryōsaku ŭi yŏkhal-Kungnip chungang pangmulgwan sojang Chosŏn ch'ongdokpu pangmulgwan kongmunsŏ ŭi kŏmt'o. Han'guk sanggosa hakpo 91: 121-41.

Kungnip Kyŏngju munhwajae yŏn'guso. 2020. Kyŏngju Namsan ŭi pulchŏk: ŏje wa onŭl. Kyŏngju: Kungnip Kyŏngju munhwajae yŏn'guso.

Lee, Seunghye. 2021. Yi wangga pangmulgwan pulsang k'ölleksyŏn ŭi hyŏngsŏng kwa ŭimi. Misulsahak yŏn'gu 309: 107-44.

Maliangkai, Roald. 2017. Broken Voices: Postcolonial Entanglements and the Preservation of Korea's Central Folksong Traditions. Honolulu: University of Hawai'i Press.

Oguma, Eiji. 2014. The Boundaries of 'the Japanese' Volume 1: Okinawa 1868-1972-Inclusion and Exclusion. Translated by Leonie R. Stickland. Melbourne: Trans Pacific Press.

Okumura, Naoji. 1924. Aru ongakuka no tabinikki kara Bukkokuji kō. Chosen oyobi Manshū 27: 201.

Ōsaka, Kintaro (Ōsaka, Rokusen). 1931. Shumi no Keishū. Kyŏngju: Keishū koseki hozonkai.

Pai, Hyung Il. 2001. The Creation of National Treasures and Monuments: The 1916 Japanese Laws on the Preservation of Korean Remains and Relics and Their Colonial Legacies. Korean Studies 25: 72-95. [CrossRef]

Pai, Hyung Il. 2010. Resurrecting the Ruins of Japan's Mythical Homelands: Colonial Archaeological Surveys in the Korean Peninsula and Heritage Tourism. In The Handbook of Post-colonialism and Archaeology. Edited by Jane Lydon and Uzma Rizvi. Walnut Creek: Left Coast Press, pp. 93-112.

Pai, Hyung Il. 2013a. Heritage Management in Korea and Japan: The Politics of Antiquity E Identity. Seattle: The University of Washington Press.

Pai, Hyung Il. 2013b. Staging 'Koreana' for the Tourist Gaze: Imperialist Nostalgia and the Circulation of Picture Postcards. History of Photography 37: 301-11. [CrossRef]

Park, Young-sin. 2021. Making “Modern” Korean Subjects: The Chosŏn Industrial Exhibition of 1915. Journal of Asian Humanities at Kyushu University 6: 1-23. [CrossRef]

Schmid, Andre. 2002. Korea between Empires, 1895-1919. New York: Columbia University Press.

Sharf, Robert H. 1995. The Zen of Japanese Nationalism. In Curators of the Buddha: The Study of Buddhism under Colonialism. Edited by Donald S. Lopez Jr. Chicago: The University of Chicago Press, pp. 107-60.

Takagi, Hiroshi. 2004. Ilbon misulsa wa Chosŏn misulsa ŭi sŏngnip. In Kuksa ŭi sinhwa rŭl nŏmŏsŏ. Edited by Im Jihyŏn and Yi Sŏngsi. Seoul: Humanist, pp. 165-96.

Wu, Hung. 2012. A Story of Ruins: Presence and Absence in Chinese Art and Visual Culture. Princeton: Princeton University.

Yamamoto, Kōtarō. 1914. Saishin Chōsen ijū annai. Tokyo: Minyūsha.

Yi, Sunja. 2008. Ilche kangjŏmgi kojŏk chosa saŏp yŏn'gu. Seoul: Kyŏngin munhwasa.

Yun, Kyŏngnyŏl. 1997. Majimak Sillain Yun Kyŏngny̆l. Seoul: Hakkojae.

Yun, Soyŏng (Yoon, So-young). 2009. Singmin t'ongch'i p'yosang konggan Kyŏngju wa t'uŏrijŭm: 1910-1920 nyŏndae Ilbonin ŭi yŏhaenggi rŭl chungsimŭro. Tongyanghak 45: 159-83. 